\title{
Optimal timing for initiation of antiretroviral therapy: a prospective study on treatment naive HIV patients
}

\author{
Jaya Chakravarty ${ }^{*}$, Avinash Singh, Anup Singh, Madhukar Rai, Anoop Gupta, Amit Agarwal, Shyam Sundar \\ From First International Science Symposium on HIV and Infectious Diseases (HIV SCIENCE 2012) \\ Chennai, India. 20-22 January 2012
}

\section{Background}

Early institution of therapy has been advocated worldwide. However, until recently, NACO guidelines recommended therapy in HIV positive patients with CD4 count $<250 / \mu \mathrm{L}$. In this study we observed the clinical and immunological disease progression for a year in treatment naïve patients with CD4 count between $250-500 / \mu \mathrm{L}$.

\section{Method}

150 treatment naïve adults PLHIV with CD4 count between $250-500 / \mathrm{mm}^{3}$ in WHO clinical stage 1 or 2 were included in the study and enrolled into 2 groups at 2:1 ratio and followed for 1 year. Group A with CD4 count between $250-350 / \mathrm{mm}^{3}$ \& Group B with CD4 count between $350-500 / \mathrm{mm}^{3}$. At the end of study each group was evaluated for number of opportunistic infection, ART conversion, conversion to stage III and IV, lost to follow up (LFU) and death. Statistical analysis was done by SPSS 16.0 version. Data were expressed as mean $( \pm$ SD) for continuous variable and percentage for categorical variable. An independent sample t-test was used to detect differences in clinical and laboratory results.

\section{Result}

As compared to Group B, Group A had significantly higher number of opportunistic infection $(27 \%$ vs $8 \%$, $\mathrm{p}=0.006)$, ART conversion ( $30 \%$ vs $10 \%, \mathrm{p}=0.012$ ), death (9\% vs $0 \%, \mathrm{p}=0.021)$ and $\mathrm{LFU}(20 \%$ vs $6 \% \mathrm{p}=0.037)$.

\section{Conclusion}

This study reinforces the need of early initiation of treatment in patients with $\mathrm{CD} 4<350 / \mu \mathrm{L}$.

* Correspondence: tapadar@gmail.com

Department of Medicine, Institute of Medical Sciences, Banaras Hindu University, Varanasi, UP, India
Published: 4 May 2012

doi:10.1186/1471-2334-12-S1-P38

Cite this article as: Chakravarty et al:: Optimal timing for initiation of antiretroviral therapy: a prospective study on treatment naive HIV patients. BMC Infectious Diseases 2012 12(Suppl 1):P38.
Submit your next manuscript to BioMed Central and take full advantage of:

- Convenient online submission

- Thorough peer review

- No space constraints or color figure charges

- Immediate publication on acceptance

- Inclusion in PubMed, CAS, Scopus and Google Scholar

- Research which is freely available for redistribution

\section{() Biomed Central}

\section{Biomed Central}

